\title{
Daniel Calparsoro
}

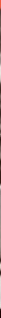

Ann Davies

SPAAISH AND

LATIN AMERICAN

FILMMAKERS 


\section{Daniel Calparsoro}

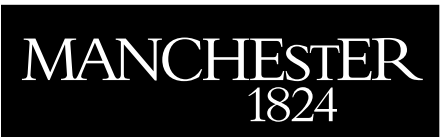

Manchester University Press 


\section{Spanish and Latin American Filmmakers}

Series editors:

Núria Triana Toribio, University of Manchester

Andy Willis, University of Salford

Spanish and Latin American Filmmakers offers a focus on new filmmakers; reclaims previously neglected filmmakers; and considers established figures from new and different perspectives. Each volume places its subject in a variety of critical and production contexts. The series sees filmmakers as more than just auteurs, thus offering an insight into the work and contexts of producers, writers, actors, production companies and studios. The studies in this series take into account the recent changes in Spanish and Latin American film studies, such as the new emphasis on popular cinema, and the influence of cultural studies in the analysis of films and of the film cultures produced within the Spanish-speaking industries.

Already published

The cinema of Álex de la Iglesia Peter Buse, Núria Triana Toribio and Andy Willis

Julio Medem Rob Stone

Emilio Fernandez: pictures in the margins Dolores Tierney 


\section{Daniel Calparsoro}

\section{Ann Davies}

Manchester University Press

Manchester and New York

distributed exclusively in the USA by Palgrave Macmillan 
Copyright (C) Ann Davies 2009

The right of Ann Davies to be identified as the author of this work has been asserted by her in accordance with the Copyright, Designs and Patents Act I988.

Published by Manchester University Press

Oxford Road, Manchester Mi3 9NR, UK

and Room 400, I75 Fifth Avenue, New York, NY ıоoı, USA

www.manchesteruniversitypress.co.uk

Distributed in the United States exclusively by

Palgrave, I75 Fifth Avenue, New York,

NY Iо०Iо, USA

Distributed in Canada exclusively by

UBC Press, University of British Columbia, 2029 West Mall,

Vancouver, BC, Canada V6T IZ2

British Library Cataloguing-in-Publication Data

A catalogue record for this book is available from the British Library

Library of Congress Cataloging-in-Publication Data applied for

ISBN 978 ○ 7190 73649 hardback

First published 2009

I8 I7 I6 I5 I4 I3 I2 II I0 o9 I0 9877654432 I

Typeset in Scala with Dax display

by Koinonia, Manchester

Printed by the MPG Books Group in the UK 